\title{
Mongolia's potential in international cooperation in the Asian energy space
}

\author{
Sereeter Batmunkh ${ }^{1}$, Valery Stennikov ${ }^{2, *}$, Bayar Bat-Erdene ${ }^{3}$, and Altay Erdenebaatar ${ }^{4}$ \\ 1,3,4 Mongolian State University of Science and Technology \\ ${ }^{2}$ Melentiev Energy Systems Institute of Siberian Branch of the Russian Academy of Sciences, 130, \\ Lermontov str., Irkutsk, 664033, Russia
}

\begin{abstract}
The paper is concerned with the issues of interstate electric power interconnections to be created in the countries of Northeast Asia. The conditions are formulated, the problems are stated, and solutions for Mongolia's entry into the Asian energy space are proposed. The electricity consumption rates are growing, however, the Northeast Asia countries differ considerably in available energy resources to cope with this growth. Therefore, the need to build international electric power interconnections that take into account climatic features, seasonal peak load differences and other factors in order to rationally match power demand and supply is getting increasingly more obvious. Mongolia can take an active part in this process, as the country is rich in energy resources and interested in their development to meet their domestic needs and exchange with neighboring countries. The establishment of interstate power interconnections in the Northeast Asia countries represents a topical task whose solution will make it possible to meet the demand of this region for electricity on mutually beneficial terms. Mongolia has a good spatial position, energy resources and is interested in ensuring domestic energy balance. Therefore, the country can be an active participant in such an integration process.
\end{abstract}

\section{Introduction}

In light of noticeable differences in the levels of general development of the countries, availability of renewable (wind, solar, hydro) and traditional fossil energy resources, the issues of electricity import and export have become an indispensable part of energy policy of many countries in the world. Therefore, energy market is expanding, first of all, to the neighboring countries. The principle of energy market expansion is based, as is known, on the construction and development of interstate power interconnections that can be exemplified by the following currently operating interconnections: [1]

1. Eastern and Western Grid in the USA.

2. ENTSO-E (European network of system operator in electric power industry in Europe.

3. Unified power system/Interconnected power system of NIS and Baltic Countries.

\footnotetext{
* Corresponding author: sva@isem.irk.ru
} 
4. Greater Mekong electricity subregional market.

5. SAARC (South-Asian Association for Regional Cooperation) Power Grid in Asia.

An interstate power interconnection to be created as a single technical system offers good possibilities of ensuring mutually beneficial power trade, reliability of uninterrupted power supply to the regions, increase in the efficiency of installed capacities at various power plants, technological advance of energy infrastructure, creation and expansion of green electricity generation and solving environmental problems, and construction of largescale joint power facilities in the member countries of this interconnection.

An analysis of the international experience shows that interstate power interconnections tend to be constructed in a limited territory, including two and more states or in the offshore zones.

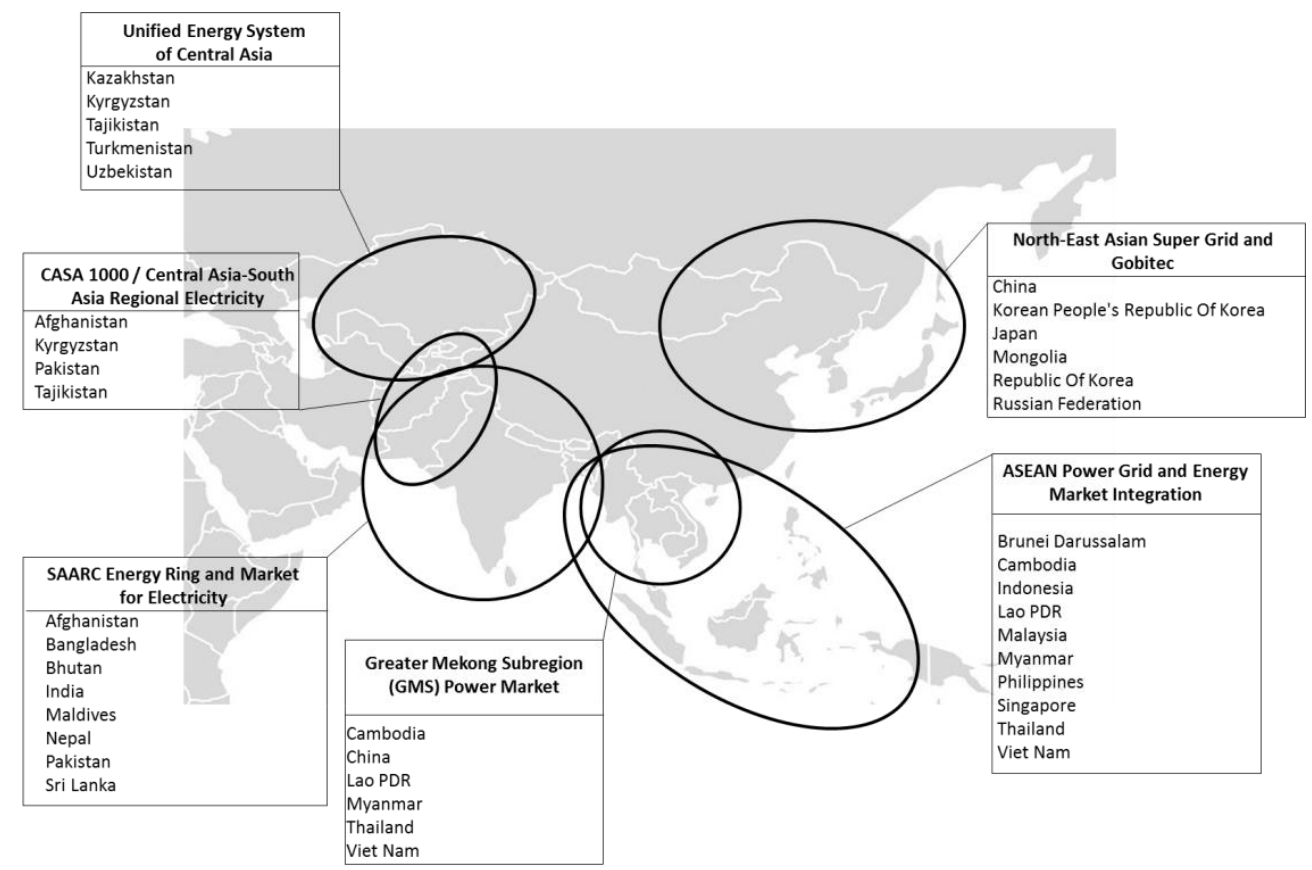

Fig. 1. Some projects on interstate power interconnections in Asia and Asia-Pacific region.

The studies on the construction and development of the interstate power interconnections are mainly aimed at the creation of large capacities involving renewable energy sources (solar, wind and hydro) to eliminate shortage of generation capacity of conventional energy sources, on the one hand, and to provide favorable environment, on the other hand. For example, China is building solar and wind integrated systems, Mongolia is doing research on the construction of such integrated systems in the Gobi desert [2]. These systems are further planned to be part of the interstate power interconnection in Northeast Asia - Asian Super Grid (Fig. 2) [3].

\section{Potential of Mongolia's participation in the energy cooperation}

In order to take part in the interstate power interconnection in Northeast Asia (Asian Super Grid), Mongolia can undertake the construction of high-power power plant on the basis of available renewable energy sources in the Gobi desert, and construction of high-voltage $\mathrm{AC}$ and DC transmission lines, which will ensure stable energy development. It is worth 
noting that there are other countries interested in participation in this project. These are Russia, China, Japan and South Korea. Currently, serious studies are being conducted to determine the development prospects for this region [3, 4]. Some of these countries border one another, have long experience of successful trade cooperation, have sufficient investment and financial capabilities to construct large heat, electricity, hydro and nuclear power plants. Russia jointly with China and Japan, and China with the Democratic People's Republic of Korea started the implementation of the first joint large-scale energy projects [5-8] which can underlie the creation of the interstate power interconnection in Northeast Asia. The possibility of participation and role of Mongolia in the project "Asian Super Grid" $[9,10]$ cause the need to carry out scientifically-grounded research aimed at determining the sites for the new generation capacities, considering spatial distribution of energy resources in the regions and situation in the electricity markets.

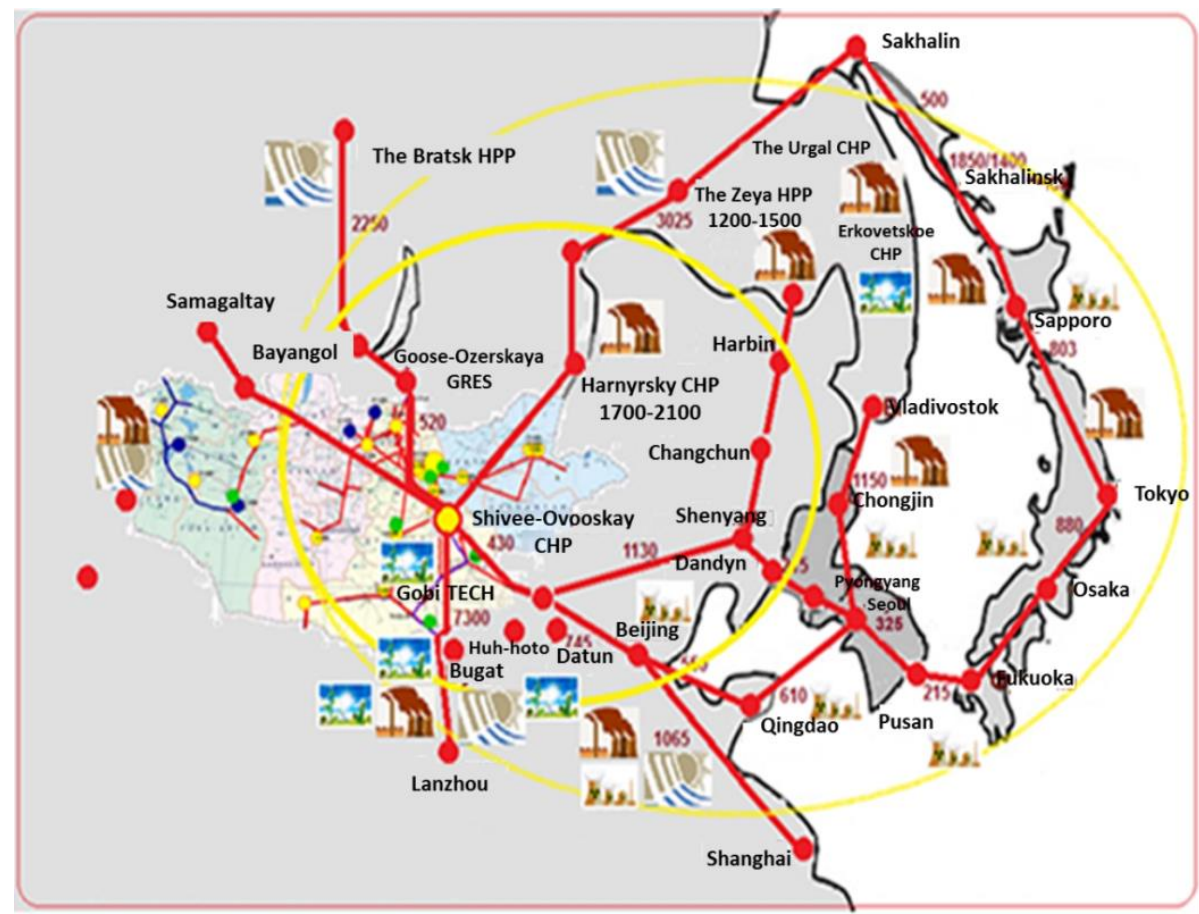

Source: A preliminary report on the participation of Mongolia in the NEA interstate power interconnection. National RES Center. 2015.

Fig. 2. A general scheme of the proposed interstate power interconnection of Northeast Asia - "Asian Super grid".

Investors participating in the international forums have been refusing lately to fund the construction of coal-fired power plants polluting the environment. In the context of major accidents at nuclear power plants that had negative consequences, the world community is against the construction and operation of nuclear power plants. These circumstances foster the revision of energy policy in many countries and its shift in favor of renewable energy. The identical trends are observed in Mongolia that apart from considerable traditional resources has also substantial renewable energy resources. The forecast coal reserves in this country account for 175 billion $t$, oil - 205 million t, uranium - 68 million $t[11,12]$. According to the assessment of the National Renewable Energy Laboratory of the USA, Mongolia is rich in wind energy resources, their forecast power is $1100 \mathrm{GW}$ (only $10 \%$ of the country's territory have specific power above $600 \mathrm{~W} / \mathrm{h}$ ) [2]. According to the report of 
Energy Charter issued in 2014, the anticipated power based on the use of solar energy can make up $2500 \mathrm{GW}[2,9,10]$. Graphical representation of this potential is demonstrated in Fig. 3.

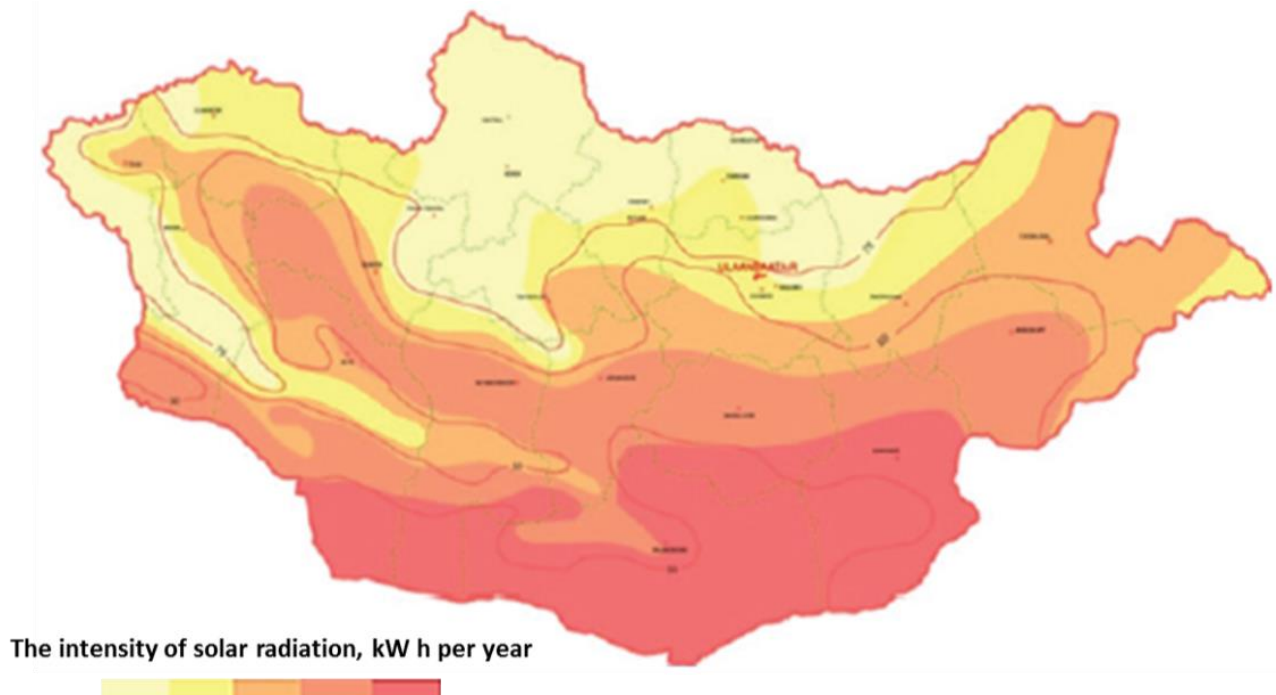

Less 1200130014001500 Over

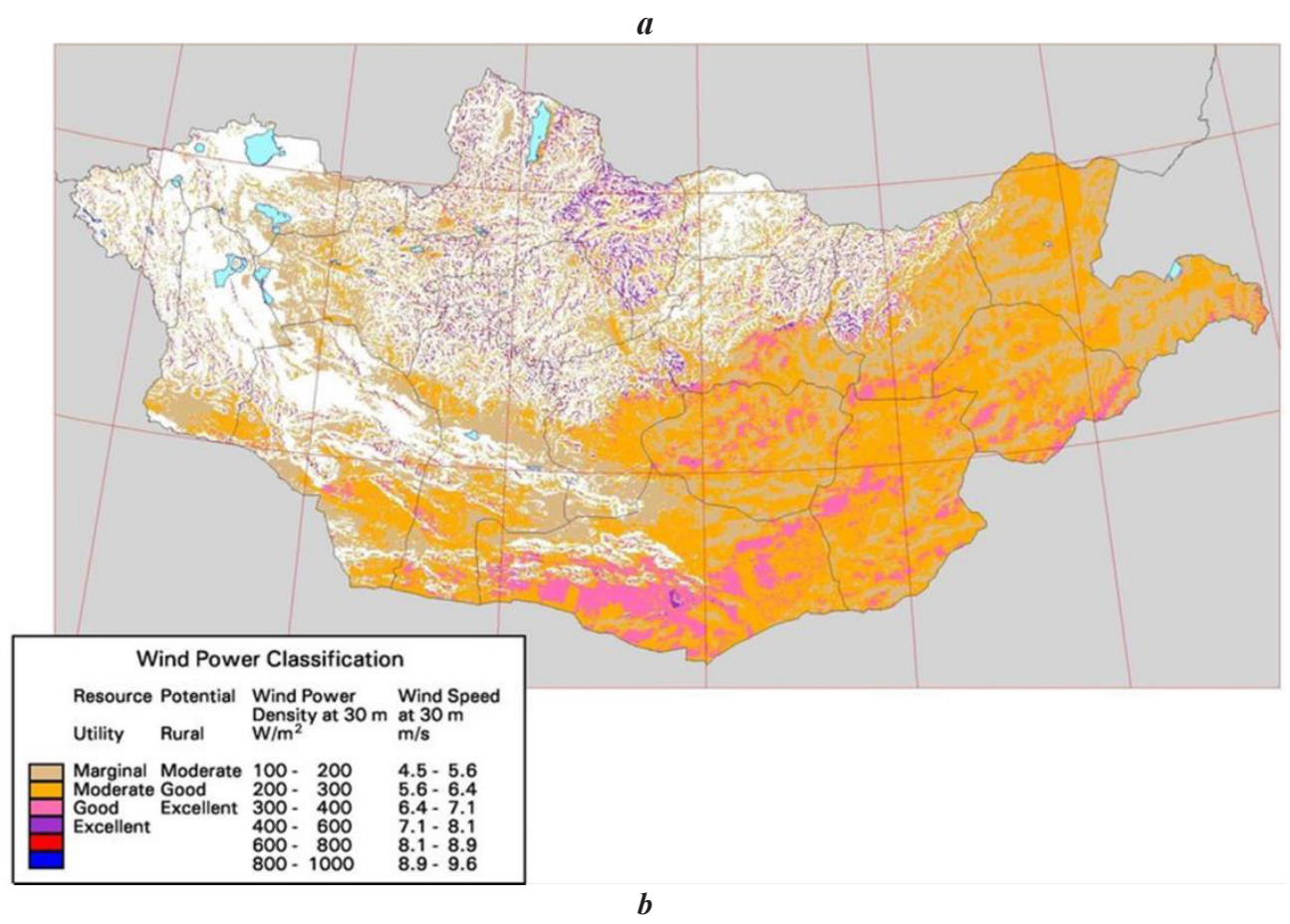

Fig. 3. Average annual solar(a) and wind (b) resources in the planned solar-wind system "Gobitech".

Despite substantial energy resources of various kinds (conventional and unconventional), there is power shortage which has been growing lately along with a 
permanent annual increase (by 7-10\%) in electricity consumption [13]. Unfortunately, no measures are taken to eliminate the shortage and cope with this situation, unfavorable for the economy. For example in 2016 electricity import from the neighboring countries reached 1420 million $\mathrm{kWh}$, its main part makes up the difference of the two-way power flow by the interstate transmission line Mongolia - Russia. The established energy cooperation is normally focused on electricity import. However, at the same time it is obvious that such a cooperation principle is not optimal to integrate the power systems of neighboring countries, and to create and develop the interstate power interconnection in Northeast Asia.

\section{Specific features of the interstate power interconnection and new opportunities for Mongolia}

The interstate power interconnection in Northeast Asia (Asian Super Grid) is still in the initial stage. Currently, there are only individual transboundary transmission lines mainly with a voltage of $110-220 \mathrm{kV}$ with a transfer capability of 100-150 MW. These transboundary lines include the existing lines between Russia and Mongolia, Russia and China, China and North Korea, China and Mongolia [6-8]. Since 2011 an export 500 kV transmission line connecting the Amur substation (RF) and the Heihe substation (China) with a transfer capability of $750 \mathrm{MW}$ and a DC link has been in operation $[14,15]$.

The investigations into the interstate power interconnections involve research institutes of Russia, including those of the Russian Academy of Sciences, Republic of Korea, China, Japan, Mongolia and other countries, and Asia-Pacific Energy Research Center in Tokyo (Japan). A generalized characteristic of power industries of potential participants in the large-scale project “Asian Super Grid” is presented in Table 1.

Table 1. A generalized characteristic of power industry of Mongolia and the NEA countries.

\begin{tabular}{|c|c|c|c|c|c|c|c|}
\hline \multirow[b]{2}{*}{ Index } & \multirow[b]{2}{*}{$\begin{array}{l}\text { China } \\
(2013)\end{array}$} & \multicolumn{2}{|c|}{ Russia } & \multirow[b]{2}{*}{$\begin{array}{c}\text { Republic } \\
\text { of Korea } \\
(2013)\end{array}$} & \multirow[b]{2}{*}{$\begin{array}{l}\text { Japan } \\
(2012)\end{array}$} & \multirow[b]{2}{*}{$\begin{array}{l}\text { Mongolia } \\
\text { (2012) }\end{array}$} & \multirow[b]{2}{*}{$\begin{array}{l}\text { DPRK } \\
(2012)\end{array}$} \\
\hline & & $\begin{array}{l}\text { Siberia* } \\
(2013)\end{array}$ & $\begin{array}{l}\text { The Far } \\
\text { East* } \\
\text { (2013) }\end{array}$ & & & & \\
\hline $\begin{array}{l}\text { Area of the territory, } \\
\text { million } \mathrm{km}^{2}\end{array}$ & 9598 & 5115 & 6169 & 99 & 373 & 1565 & 121 \\
\hline Population, million people & 1357.4 & 19.3 & 6.3 & 50.0 & 127.6 & 2.8 & 24.8 \\
\hline $\begin{array}{l}\text { Power consumption, } \\
\text { TWh }\end{array}$ & 5322.3 & 205.3 & 31.61 & 474.9 & 991.6 & 5.2 & 1.2 \\
\hline $\begin{array}{l}\text { Power consumption per } \\
\text { capita, } \mathrm{kWh} / \text { person }\end{array}$ & 3921 & 10637 & 5017 & 9498 & 7771 & 1857 & 734 \\
\hline Power generation, TWh & 5347.4 & 197.4 & 35.2 & 517.1 & 1094.0 & 5.2 & 21.5 \\
\hline $\begin{array}{l}\text { Installed capacity of } \\
\text { power plants, GW }\end{array}$ & 1247.4 & 49.3 & 9.1 & 91.0 & 287.3 & 1.02 & 7.22 \\
\hline $\begin{array}{l}\text { including } \\
\text { Thermal power plants: }\end{array}$ & 796.4 & 25.0 & 5.7 & 56.3 & 188.9 & 0.97 & 2.96 \\
\hline coal-fired & 758.1 & 24.2 & 5.2 & 24.5 & 50.9 & 0.88 & 2.76 \\
\hline gas and heavy oil-fired & 38.3 & 0.8 & 0.5 & 31.8 & 138.0 & 0.09 & 0.2 \\
\hline Hydropower plants & 280.0 & 24.3 & 3.3 & 6.5 & 48.9 & 0.03 & 4.26 \\
\hline Nuclear power plants & 14.6 & - & - & 20.7 & 46.1 & - & - \\
\hline Renewable energy sources & 86.8 & - & - & 3.5 & 3.4 & 0.01 & - \\
\hline
\end{tabular}

*Power generation, power consumption, and installed capacity are given for interconnected power systems of Siberia and the Far East, respectively. 
With the proper energy policy and scientifically grounded concept of Mongolia's energy development, this country can take an appropriate place in the energy space of Northeast Asia, and its role in the construction and expansion of the interstate power interconnection in Northeast Asia (Asian Super Grid) can become significant. Implementation of such a concept will open up the following possibilities at least for Mongolia:

1. The regions of Northeast Asia with a high demand for electricity due to shortage of energy resources will be provided with electricity.

2. The renewable power generation will become more uniform and its efficiency will rise.

3. Mongolia's electricity export and import will change qualitatively: the country will turn from an importing country into an exporting-importing country.

Solving these problems foregrounds the technical and technological issues related to the connection of the regions by interstate UHV $500,750 \mathrm{kV} \mathrm{AC}$ and $\pm 400, \pm 600, \pm 800 \mathrm{kV}$ DC overhead and cable transmission lines.

\section{Formation of electricity market}

The above circumstances and the level of the country development generate the need to develop a national concept of Mongolia's participation in the large-scale project of Interstate power interconnection in Northeast Asia. To preserve and expand its energy market in the near future Mongolia should first of all solve the following problems:

1. Take measures to create favorable conditions to attract investors from interested countries, including those from Mongolia.

2. Based on Mongolia's energy development strategy, perform a feasibility study and then implement the projects for construction of new power sources and transmission lines jointly with stakeholders concerned. In the low-population areas of the desert, it is necessary to envisage the construction of solar and wind power plants with a capacity of above $4000 \mathrm{MW}$, and new transboundary overhead transmission lines.

3. Organize energy cooperation with the NEA countries; enhance the effectiveness of such integration-based cooperation, considering seasonal load differences in each country, difference in time zones and specific features of climatic conditions.

The creation of the power interconnection infrastructure requires first of all interest and support of neighboring and other countries, as well as a feasibility study on export-import power delivery.

According to the authors of $[1,4]$, Mongolia has a transboundary $220 \mathrm{kV}$ overhead transmission line connected with the electric power systems of Russia and China. This makes it possible to gain the necessary experience in operation of such lines. In the event of the development and expansion of operating interstate electric ties involving huge renewable energy resources of the Gobi area and coal, Mongolia can make a great impact on the formation and expansion of the interstate electric ties in NEA.

Japan is second only to China in the level of electricity production and consumption in the region. At the same time, this country is the first in nuclear energy development in NEA. Due to the limited indigenous natural energy resources, and imported power to meet domestic demand, Japanese power industry should solve two problems: decrease reliance on power import and reduce unfavorable impact of thermal power industry on the environment. In these conditions, the expansion of interstate electric ties with neighboring countries and import of green electricity from Russia and China could considerably improve the environmental situation in the country and meet external electricity demand. Different projects are offered for transboundary transmission lines between Japan and these 
countries. These however require additional feasibility studies on the construction of overhead and cable transboundary transmission lines.

South Korea is characterized by a very high level of power industry development. This country is a leader in electricity production per capita compared to the other NEA countries (Table 2). The structure of generation capacities in South Korea is similar to that in Japan. Korea is highly interested in green power import from Russia and China. However, it encounters serious political and financial barriers.

Table 2 presents the indices of energy available in NEA countries, and the world electricity production and consumption compared to these indices for Mongolia.

The data are of interest in terms of specific electricity consumption (per capita) that varies greatly with respect to the average level.

Canada, the USA and South Korea from NEA countries stand out in terms of per capita electricity consumption. Mongolia power consumption index is below the average level. However, this country has favorable conditions for the improvement of this index owing to enormous reserves of traditional and renewable energy. Moreover, this allows Mongolia to participate in electricity market as a power exporter.

Table 2. Global power production and consumption.

\begin{tabular}{|c|l|c|c|c|}
\hline No & \multicolumn{1}{|c|}{ Countries } & $\begin{array}{c}\text { Generation } \\
\text { GWh }\end{array}$ & $\begin{array}{c}\text { Population, } \\
\text { thousand }\end{array}$ & $\begin{array}{c}\text { Consumption per capita } \\
\mathrm{kWh} / \text { person }\end{array}$ \\
\hline 1 & China & 5649500 & 1376622 & 4103.89 \\
\hline 2 & USA & 4297300 & 323394 & 13288.13 \\
\hline 3 & India & 1208400 & 1288306 & 937.98 \\
\hline 4 & Russia & 1064100 & 146545 & 7261.25 \\
\hline 5 & Japan & 1061200 & 126980 & 8357.22 \\
\hline 6 & Germany & 614000 & 81174 & 7564.00 \\
\hline 7 & Canada & 615400 & 34850 & 17658.54 \\
\hline 8 & Brazil & 582600 & 205738 & 2831.76 \\
\hline 9 & France & 555700 & 64513 & 8613.77 \\
\hline 10 & Republic of Korea & 517800 & 51431 & 10067.86 \\
\hline 11 & Mongolia & 5541.7 & 3000 & 1847.23 \\
\hline 12 & Niue & 3 & 14 & 214.29 \\
\hline \multicolumn{2}{|l}{ Total in the world } & 23536500 & 7300000 & 3224.18 \\
\hline
\end{tabular}

\section{Prospects for the interstate power interconnection in Northeast Asia ("Asian Super Grid")}

The studies [1, 3-8] show that the prospects for the power industry integration in Northeast Asia are determined by the projects for the development of interstate electric ties in the energy sector and large-scale projects on the interstate power interconnections. The projects differ in the form of cooperation: transboundary trade, power export, connection of national or local electric power systems of neighboring countries for joint (or parallel) operation; structure of generating capacities (relationship between power sources of various types); technical and technological solutions for transboundary transmission lines (Table 3). 
Among the potential directions of interstate electric ties in NEA, that are presented in Table 3, of interest is transmission of power generated from a solar-wind system in the Gobi desert.

Table 3. Prospective interstate electric ties among NEA countries.

\begin{tabular}{|l|c|c|c|c|c|}
\hline \multicolumn{1}{|c|}{ Interstate electric ties } & $\begin{array}{c}\text { Length, } \\
\mathrm{km}\end{array}$ & $\begin{array}{c}\text { Voltage, } \\
\mathrm{kV}\end{array}$ & $\begin{array}{c}\text { Transfer } \\
\text { capability, } \\
\mathrm{GW}\end{array}$ & $\begin{array}{c}\text { Transmitted } \\
\text { power, } \\
\mathrm{TWh} / \text { year }\end{array}$ & $\begin{array}{c}\text { Tentative } \\
\text { cost, billion } \\
\text { USD }\end{array}$ \\
\hline \multicolumn{7}{|c|}{ Russia - China } \\
\hline Bratsk - Ulan-Bator - Beijing & 2250 & \pm 600 & $5-6$ & 18 & 1,8 \\
\hline Bureya HPP - Harbin & 700 & \pm 400 & 1,0 & 3 & 2,2 \\
\hline Large-scale power export project & $3400^{*}$ & \pm 600 & $10^{*}$ & $60^{*}$ & $18^{*}$ \\
\hline Erkovetskaya CPP - Shenyang & 1300 & \pm 600 & 3,6 & 20 & 8,8 \\
\hline $\begin{array}{l}\text { DC system "Ust-Ilimsk - Russia - Korean peninsula } \\
\text { Khabarovsk" }\end{array}$ & 5000 & \pm 750 & 10,0 & 40 & 16,5 \\
\hline \multicolumn{7}{|c|}{ Russia - Japan } \\
\hline Vladivostok - Chongjin & 1150 & \pm 500 & 0,5 & 3 & 0,13 \\
\hline Vladivostok - Pyongyang - Seoul & \pm 500 & 4,0 & 7 & 4,8 \\
\hline South-Yakutian HPPs - Shenyang \\
Seoul
\end{tabular}

* generalized project indices.

** in numerator- total length, in denominator - length of submarine cable.

Russia proposes the projects for the hydropower plants oriented to long-distance power transmission. One of them is a $9050 \mathrm{MW}$ hydropower plant on the Lena river, currently under design. Average annual output makes up 7.8 TWh, the hydropower plant construction cost is about 3.6 billion USD. It is also planned to construct Mokskaya HPP on the Vitim river in the Republic of Buryatia. Power generated by this plant will be supplied to deficient regions in the Far East, Mongolia and China. The Bureya and Zeya HPPs operating in the Amur power system can also be considered export-oriented. Implementation of these projects will enable power supply to consumers in Siberia and the Far East. Moreover, they will undoubtedly contribute to the increase in the maneuverability of the transboundary power transmission, and enhancement of the efficiency of transboundary power systems.

Involvement of Mongolia's power system in the project "Bratsk - Ulan-Bator Beijing" aimed at exporting surplus power from the Siberian power system can enhance the efficiency of this project, and create good conditions for power export to neighboring countries. In 2005, JSC "RAO UPS of Russia" and State Grid Corporation of China concluded a contract on mutually beneficial energy cooperation. According to this contract, Russia should export 60 trillion kWh to China annually [13]. The first stage of this project ended with connection of the Far Eastern electric power system to the power system of Heihe (Northeast Province of China). This enables the interconnected power system of the East to supply up to 3.5 billion $\mathrm{kWh}$ of power yearly to the northeastern provinces of China. 
The most effective project among these is the interconnection of the regional power system of the Far East with the power system of the Republic of Korea through the transboundary transmission line "Vladivostok - Pyongyang - Seoul", $1150 \mathrm{~km}$ long. The expected economic benefit, i.e. saving of investment, from interconnecting the capacities and using the difference in time zones (9-11 hours) reaches 6-7 billion USD [1].

Another interesting project of transboundary power transmission is the project "Sakhalin - Hokkaido - Honshu", the so called "power bridge". The idea of this bridge appeared in the 1990s. This project suggests the construction of two export-oriented condensing power plants (4 GW Solntsevskaya coal-fired power plant - in the first stage, and Vakhrushevskaya combined cycle power plant - in the second stage), and $\pm 400 \mathrm{kV}$ DC transmission line "Sakhalin - Sapporo - Tokyo", $1600 \mathrm{~km}$ long, with two submarine cables at the bottom of the La Perouse Strait $(50 \mathrm{~km})$ and Sangarsky strait $(40 \mathrm{~km})$.

Participation in the construction and development of the NEA interstate power interconnection (Asian Super Grid) requires that Mongolia perform a feasibility study on the construction of the wind -solar system in the Gobi desert (Gobitec) to export cheap power to China, Republic of Korea, Japan, and Russia, and further implement the project. In this context it will be first of all necessary to solve the issue of constructing a $( \pm 600 \mathrm{kV})$ DC transmission line and a $(500 \mathrm{kV}) \mathrm{AC}$ transmission line.

The creation of the $100 \mathrm{GW}$ wind-solar system in the Gobi desert will give an impetus to the construction of Asian Super Grid and creation of several interconnections: A Mongolian ring: Gobitec - Mugden - Harbin - Kharanuur; the Japanese Sea ring: Seoul Pyongyang - Hokkaido - Honshu; and a big ring: Bratsk - Urgalsk - Sakhalin - Tokyo Shanghai - Beijing - Ulan-Bator - Irkutsk (Fig.1). This project will obviously have a longterm implementation period but it will have a tremendous benefit, for example, a reduction in the fuel costs alone will make up 10.0 trillion USD a year.

\section{Conclusion}

The interstate electric power interconnections start with the construction of transboundary transmission lines ensuring joint operation of national or local power systems of two, less often three countries. Such transmission lines tend to operate in an alternate mode, and this allows the countries involved to enjoy the synergetic effect. A comparative analysis of the expansion and operation costs of electric power systems of neighboring countries for the cases of their integration and their independent operation shows that such electric ties can be rather effective. This can be exemplified by the interstate power bridges: "Bratsk - UlanBator - Beijing"; "Vladivostok - Pyongyang- Seoul"; Shivee - Ovoo- Kharanuur Sakhalin"; Shivee - Ovoo - Shenyang - Pyongyang - Seoul" and other transboundary transmission lines connecting power systems of different countries with non-coincident seasonal peak loads. Active participation of Mongolia in the interstate power interconnection in NEA requires that Shivee- Ovoo energy facility and Gobitec be connected to the electric network covering the Russian Far East; Northern and Northeastern regions of China; Japan; South and North Korea.

To summarize, we can conclude that there are a lot of proposals for the interstate power interconnection of electric power systems. However, they are not coordinated with one another, therefore the parties concerned, involved in the NEA interstate power interconnection should carry out joint scientifically grounded studies to solve the energy issues existing in these countries. 


\section{References}

1. Yu.N. Kucherov, O.M. Kucherova, L. Kapoji, Yu.N. Rudenko, Reliability and effectiveness of large-scale trans-national electric power systems (Novosibirsk, Nauka. 1996) (In Russian)

2. In-depth review of the investment climate and market structure in the energy sector of Mongolia (Belgium, Energy Charter Secretariat, 105, 2013) http://www.energycharter.org/fileadmin/DocumentsMedia/ICMS/ICMSMongolia_2013_ru.pdf

3. H. Bahar, J. Sauvage, OECD Trade and Environment Working Papers, 2, 78 (2013)

4. Eastern vector of Russia's energy strategy. Current state, look into the future (Novosibirsk, Geo. 2011) (In Russian)

5. S. Mano, B. Ovgor, Z. Samadov etc, Gobitec and Asian Super Grid for Renewable Energies in Northeast Asia (Belgium, Energy Charter Secretariat. 2014)

6. Wind Energy Resource Atlas of Mongolia, National Renewable Energy Laboratory (NREL/TP-500-28972., US. 2001) https://digital.library.unt.edu/ark:/67531/metadc721321/

7. J.Y. Yoon, D.W. Park, H.Y. Kim, Proceeding of 6th International Conference - Asian Energy Cooperation:Forecast and Realities (Irkutsk, 2008) (In Russian)

8. W. Chandler, Ch. Shiping, H. Gwin, L. Ruosida, W. Yanjia, WWF Report, 2, 71 (2014)

9. Mongolia 's Climate Reference Book (Ulan-Bator, GMS. 1984)

10. Climate of Mongolia (Ulan-Bator, Gosizdat. 1985)

11. Brief data on coal, oil and oil shale deposits of Mongolia, Mineral Resources and Petroleum Authority of Mongolia (Ulan-Bator, Geological Information Center. 2007)

12. Uranium resources, production of Mongolia (RED BOOK) Uranium, 2009: Resources, Production and Demand (OECD, IAEA. 2010)

13. Statistics of energy sector 2016 (Ulan-bator, Coordination Committee for the Energy Sector, 2017)

14. S.V. Podkovalnikov, V.A. Saveliev, L.YU. Chudinova, External Economic Relations. 4, 118-130 (2015) (In Russian)

15. Interconnection in APEC Region. Current Status \& Future Potential (Tokyo, Asia Pacific Energy Research Center, 2000) 